\title{
En ny generasjon troverdige kliniske retningslinjer
}

\author{
Per Olav Vandvik ${ }^{1,2}$, Rigmor Berg ${ }^{1}$ og Gunn Vist ${ }^{1}$ \\ 1) Seksjon for forebyggende, helsefremmende og organisatoriske tiltak, Nasjonalt kunnskapssenter for helsetjenesten \\ 2) Medisinsk avdeling, Sykehuset Innlandet HF-divisjon Gjøvik \\ Korrespondanse: Per Olav Vandvik, E-post: per.vandvik@gmail.com Telefon: 97512391
}

\begin{abstract}
SAMMENDRAG
Trygg og effektiv diagnostikk, pleie og behandling fordrer at helsepersonell har tilgang til oppdatert og gyldig forskningsbasert kunnskap, fortrinnsvis i form av faglige kliniske retningslinjer utviklet med tilfredsstillende metodikk. De fleste retningslinjer har imidlertid betydelige svakheter med hensyn til både kunnskapsgrunnlag, utvikling av anbefalinger, presentasjonsformater og oppdatering. Nye definisjoner, standarder og metoder for kunnskapsbaserte troverdige retningslinjer gir langt bedre muligheter enn tidligere for å lykkes i arbeidet med å utvikle og implementere retningslinjer, men stiller samtidig større krav til metodekompetanse, klinisk ekspertise og tid. I vår digitale tidsalder åpner ny nettbasert teknologi for bedre disseminering av retningslinjer til frontlinjene i klinikken, og til å dele kunnskap med pasienter i konsultasjonen, for eksempel gjennom smarttelefoner og lesebrett. Gjennom et praktisk eksempel redegjør vi i denne artikkelen for nye definisjoner, standarder, metoder og verktøy for utvikling, disseminering og oppdatering av faglige retningslinjer. GRADE-systemet er en sentral komponent $i$ dette. Det er nå mulig å lage troverdige retningslinjer som klinikere og pasienter kan ta i bruk i en travel hverdag. Det gjenstår å se hvordan myndighetene og fagmiljøene vil bidra for å sikre pasienter trygg og effektiv behandling gjennom utvikling av denne nye generasjonen av kliniske retningslinjer.
\end{abstract}

\section{Vandvik PO, Berg R, Vist G. A new generation of trustworthy clinical practice guidelines.} Nor J Epidemiol 2013; 23 (2): 197-204.

\section{ENGLISH SUMMARY}

Safe and effective diagnosis and treatment requires that health care personnel can access the best current research evidence, preferably through clinical practice guidelines. Most guidelines suffer from methodological weaknesses (e.g., identification and assessment of research evidence, development of recommendations), suboptimal presentation formats and infrequent updating of content. New definitions, standards and systems for trustworthy guidelines provide better opportunities to succeed in development and dissemination of guidelines but also increase the demand for methodological competence, clinical expertise and time. In our digital era dissemination of guidelines to clinicians and patients at the point of care is greatly facilitated by web-based technology and devices such as smart-phones and tablet computers. In this article we describe new definitions, standards, methods and tools for the creation, dissemination and updating of clinical practice guidelines, in which the GRADE system is a key component. We use a practical example to demonstrate how to make trustworthy guidelines to be used by clinicians and patients at the point of care. It remains to be seen how the authorities and professional organizations will contribute to safe and effective treatment of patients through the development of this new generation of clinical practice guidelines.

This is an open access article distributed under the Creative Commons Attribution Licence, which permits unrestricted use, distribution, and reproduction in any medium, provided the original work is properly cited.

\section{INTRODUKSJON}

Trygg og effektiv diagnostikk, pleie og behandling fordrer at helsepersonell har tilgang til oppdatert og gyldig forskningsbasert kunnskap, fortrinnsvis i form av faglige kliniske retningslinjer utviklet med tilfredsstillende metodikk (1).

De fleste retningslinjer har dessverre betydelige svakheter med hensyn til både kunnskapsgrunnlag og prosess for utvikling av anbefalinger $(2,3)$. Nye definisjoner og standarder for kunnskapsbaserte og troverdige retningslinjer ("trustworthy guidelines"), og forbedret metodikk for utvikling og evaluering av slike retningslinjer (GRADE og AGREE II) gir langt bedre muligheter enn tidligere for å lykkes med å utarbeide retningslinjer av god kvalitet $(4,5)$. En forutsetning er at disse framskrittene ledsages av tilstrekkelig metodekompetanse, klinisk ekspertise og tid for det praktiske arbeidet med å utvikle retningslinjer $(1,5)$. Dessuten er det avgiørende å sikre at troverdige kliniske retningslinjer når fram til frontlinjene i klinikken, i forståelige og anvendelige presentasjonsformater som legger til rette for at pasientene kan delta aktivt $\mathrm{i}$ beslutningsprosesser (6).

Ved hjelp av et praktisk eksempel vil vi i denne artikkelen redegjøre for nye definisjoner, standarder og metoder for utvikling, disseminering og oppdatering av faglige retningslinjer. GRADE-systemet spiller en 
Tabell 1. 8 kriterier for troverdige kliniske retningslinjer, adaptert fra "Clinical Practice Guidelines We Can Trust" (15) (1).

1. Prosessen for utvikling og finansiering av retningslinjene bør framgå i detalj, og gjøres offentlig tilgjengelig.

2. Forut for utvelgelsen av medlemmer til gruppen som skal utvikle retningslinjene, bør aktuelle kandidater oppgi alle interesser og aktiviteter de er involvert i som potensielt kan medføre en interessekonflikt, gjennom en skriftlig redegjørelse.

3. Gruppen som utvikler retningslinjene bør være tverrfaglig sammensatt, med klinikere, metodeeksperter og representanter for målpopulasjonene.

4. Retningslinjegruppen bør bruke systematiske oversikter og foreta vurderinger av kvaliteten på den samlede dokumentasjonen, inkludert faren for systematiske feil, graden av konsistens på tvers av studier, hvor presise effektestimatene er, og om resultatene er overførbare til aktuell klinisk praksis.

5. Det bør gis en forklaring for resonnementet som ligger til grunn for hver av anbefalingene som gis. Denne bør omfatte mulige fordeler og ulemper ved å følge anbefalingen, mangler ved dokumentasjonen og hvilken rolle verdier, meninger, teori og klinisk erfaring har hatt i utformingen av anbefalingen. På basis av disse vurderingene og graden av tillit gruppen har til den underliggende dokumentasjonen, bør det angis en styrke på anbefalingen.

6. Anbefalinger bør formuleres på en standardisert måte der det kommer klart fram hva den anbefalte handlingen går ut på, og når den bør utføres.

7. Utkast til nye retningslinjer bør gjennomgå omfattende ekstern vurdering, inkludert en åpen høringsprosess.

8. Retningslinjene bør oppdateres når ny dokumentasjon foreligger som tilsier at det er behov for å modifisere klinisk viktige anbefalinger.

sentral rolle i disse prosessene. Eksempelet vi vil benytte omhandler bruk av den nye platehemmeren ticagrelor ved akutt koronarsyndrom, og er hentet fra internasjonale retningslinjer for antitrombotisk behandling og tromboseprofylakse (American College of Chest Physicians, Antithrombotic Therapy and Prevention of Thrombosis, 9th Edition - ACCP AT9) $(7,8)$. ACCP AT9 ble utarbeidet i henhold til nye definisjoner for troverdige retningslinjer (9).

$\mathrm{Vi}$ beskriver til slutt hvordan en gruppe forskere og fageksperter har tilpasset ACCP AT9 til norsk bruk, og har utviklet en ny generasjon verktøy for kunnskapsstøtte til bruk i klinisk praksis på nett, brett og smarttelefoner, og integrert i elektronisk pasientjournal (10).

\section{NYE STANDARDER OG METODER FOR RETNINGSLINJEUTVIKLING}

Eksisterende faglige retningslinjer benytter ulike graderingssystemer for å vurdere kvaliteten på den underliggende dokumentasjonen, og for å angi styrken på anbefalingene som blir gitt (11). En svakhet med flere av disse systemene - utover å forvirre klinikere med ulike kombinasjoner av tall og bokstaver - er en ensidig vektlegging av studiedesign som grunnlag for graderingen. For eksempel vil en systematisk oversikt av randomiserte kontrollerte studier gjerne bli vurdert som dokumentasjon av høy kvalitet og lede fram til en sterk anbefaling. Dette til tross for at den systematiske oversikten kan være beheftet med systematiske feil, de inkluderte studiene kan ha dårlig studiekvalitet (stor risiko for skjevheter), at studiene ikke er overførbare til pasientene anbefalingen er tiltenkt, eller at balansen mellom fordeler og ulemper er hårfin.

En gjensidig problemforståelse blant internasjonale organisasjoner som har utviklet retningslinjer over de siste 20 årene har ført til utviklingen av et felles grade- ringssystem: Grading of Recommendations Assessment, Development and Evaluation (GRADE) $(11,12)$. GRADE tilrettelegger for en systematisk og transparent prosess i vurdering av kvaliteten på dokumentasjon og i prosessen fra dokumentasjon til utvikling av anbefalinger. GRADE benyttes nå av flere enn 70 ledende organisasjoner internasjonalt (13). Helsedirektoratet besluttet i 2012 å anbefale GRADE i deres "Veileder for kunnskapsbaserte faglige retningslinjer" (14).

I 2011 publiserte Institute of Medicine i USA rapporten "Clinical Practice Guidelines We Can Trust", som gir en oppdatert definisjon og nye standarder for troverdige retningslinjer (tabell 1) (1,15). Definisjonen vektlegger spesielt at anbefalinger i retningslinjer bør bygge på en systematisk gjennomgang av relevant forskningslitteratur og en balansert vurdering av fordeler og ulemper ved aktuelle behandlingsalternativer. Korrekt bruk av GRADE i retningslinjeutvikling vil medføre at de fleste av standardene fra Institute of Medicine blir oppfylt.

\section{HVORDAN LAGE TROVERDIGE KLINISKE RETNINGSLINJER?}

Utvikling av kliniske retningslinjer er en omfattende prosess dersom kriteriene gjengitt i tabell 1 skal oppfylles - som de bør. I denne artikkelen vil vi fokusere på formulering av kliniske spørsmål, vurdering av kvalitet på dokumentasjonen og utvikling av anbefalinger ved bruk av GRADE-systemet. Vi omtaler også hvordan interessekonflikter i retningslinjegrupper kan håndteres på en systematisk og transparent måte. For en nærmere beskrivelse av hvordan nye søkemotorer og systematiske litteratursøk kan brukes til å innhente den beste, tilgjengelige dokumentasjonen for en klinisk problemstilling, viser vi til en annen artikkel i dette nummeret av Norsk Epidemiologi (16). 
Tabell 2. Eksempel på PICO spørsmål, fra ACCP AT9.

\begin{tabular}{|c|c|c|c|c|c|}
\hline \multirow[t]{2}{*}{ Hva handler spørsmålet om? } & \multicolumn{4}{|c|}{ Spørsmålet i PICO format } & \multirow{2}{*}{$\begin{array}{l}\text { Tilgjengelige } \\
\text { studier }\end{array}$} \\
\hline & Populasjon & $\begin{array}{l}\text { Intervensjon } \\
\text { (tiltak) }\end{array}$ & $\begin{array}{l}\text { Komparator } \\
\text { (kontroll) }\end{array}$ & $\begin{array}{l}\text { Outcome(s) } \\
\text { (utfall) }\end{array}$ & \\
\hline \multicolumn{6}{|c|}{ 1. Sekundærprofylakse etter hjerteinfarkt } \\
\hline $\begin{array}{l}\text { Skal ticagrelor gis som tillegg til } \\
\text { acetylsalicylsyre etter akutt } \\
\text { koronarsyndrom? }\end{array}$ & $\begin{array}{l}\text { Pasienter med } \\
\text { akutt koronar- } \\
\text { syndrom }\end{array}$ & $\begin{array}{l}\text { Ticagrelor }+ \\
\text { acetylsalicylsyre }\end{array}$ & $\begin{array}{l}\text { Clopidogrel + } \\
\text { acetylsalicylsyre }\end{array}$ & $\begin{array}{l}\text { Vaskulær død } \\
\text { Hjerteinfarkt } \\
\text { Hjerneslag } \\
\text { Større blødninger }\end{array}$ & $\begin{array}{l}1 \text { RCT } \\
\text { (Wallentin L, et } \\
\text { al. NEJM 2009) }\end{array}$ \\
\hline
\end{tabular}

Tabell 3. Kvalitet på dokumentasjonen og implikasjoner for videre forskning i henhold til GRADE.

\begin{tabular}{|l|l|l|}
\hline $\begin{array}{l}\text { Høy kvalitet } \\
\oplus \oplus \oplus \oplus\end{array}$ & $\begin{array}{l}\text { Vi har stor tillit til at effektestimatet ligger nær den sanne } \\
\text { effekten. }\end{array}$ & $\begin{array}{l}\text { Det er usannsynlig at videre forskning vil } \\
\text { påvirke vår tillitt til effektestimatet. }\end{array}$ \\
\hline $\begin{array}{l}\text { Middels kvalitet } \\
\oplus \oplus \oplus \bigcirc\end{array}$ & $\begin{array}{l}\text { Vi har middels tillitt til effektestimatet: effektestimatet } \\
\text { ligger sannsynlig nær den sanne effekten, men effekt- } \\
\text { estimatet kan også være vesentlig ulik den sanne effekten. }\end{array}$ & $\begin{array}{l}\text { Det er sannsynlig at videre forskning vil } \\
\text { påvirke vår tillitt til effektestimatet. Videre } \\
\text { forskning kan også endre estimatet. }\end{array}$ \\
\hline $\begin{array}{l}\text { Lav kvalitet } \\
\oplus \oplus \bigcirc \bigcirc\end{array}$ & $\begin{array}{l}\text { Vi har begrenset tillitt til effektestimatet: effektestimatet } \\
\text { kan være vesentlig ulikt den sanne effekten. }\end{array}$ & $\begin{array}{l}\text { Det er svært sannsynlig at videre forskning vil } \\
\text { påvirke vår tillitt til effektestimatet. Videre } \\
\text { forskning vil sannsynlig endre estimatet. }\end{array}$ \\
\hline $\begin{array}{l}\text { Svært lav kvalitet } \\
\oplus \bigcirc \bigcirc \bigcirc\end{array}$ & $\begin{array}{l}\text { Vi har svært liten tillit til at effektestimatet ligger nær den } \\
\text { sanne effekten. }\end{array}$ & Effektestimatet er veldig usikkert. \\
\hline
\end{tabular}

\section{Formulering av kliniske sporsmål}

Første skritt i utvikling av anbefalinger med GRADE, på samme måte som for utvikling av systematiske oversikter, er å identifisere sentrale spørsmål for klinisk praksis, definert i såkalt PICO-format $(17,18)$. Slike kliniske spørsmål skal gi en presis beskrivelse av populasjonen $(\mathrm{P})$, behandlingsalternativene (Intervention, Comparator) og de viktige utfallene/kliniske endepunktene (Outcome). Gruppen som stod bak ACCP AT9-retningslinjene valgte å kun inkludere endepunkter som er viktige for pasienter - for eksempel ble ikke dyp venetrombose uten kliniske symptomer (påvist med ultralyd) tatt med (9). PICO-spørsmålene utgjør også et utmerket utgangspunkt for litteratursøk og identifisering av de mest relevante studiene som skal danne grunnlag for en anbefaling. I tillegg til studier som rapporterer kvantitative effektestimater for de valgte endepunkter, er det også nødvendig å finne fram til dokumentasjon som kan brukes til å anslå utgangsrisikoen for at endepunktene vil inntreffe hvis det ikke iverksettes behandling (baselinerisiko) (19). Tabell 2 gir ett eksempel på PICO-spørsmål formulert i ACCP AT9.

\section{Oppsummering av kvalitet på dokumentasjonen og fordeler/ulemper ved behandling}

Som beskrevet i nye standarder for troverdige retningslinjer (tabell 1) bør dokumentasjonen som ligger til grunn for en anbefaling være basert på en systematisk oversikt over tilgjengelige studier. Ved å bruke GRADE blir den beste tilgjengelige dokumentasjonen oppsummert gjennom en systematisk og transparent prosess $(20,21)$. Dette skjer gjennom følgende steg:
1. Kvalitet på dokumentasjonen (tillit til effektestimater) blir bestemt gjennom å vurdere åtte faktorer (21). Følgende fem faktorer vurderes dersom dokumentasjonen i hovedsak består av randomiserte kontrollerte forsøk: Risiko for systematiske feil i enkeltstudier, heterogenitet på tvers av studier, overførbarhet, presisjon av effektestimater og risiko for publiseringsskjevhet. Dersom den beste dokumentasjonen utgjøres av observasjonelle studier (for eksempel kohort eller case-control design) vurderes kvaliteten på dokumentasjonen som lav i utgangspunktet, men følgende tre faktorer kan høyne kvaliteten: En sterk sammenheng mellom tiltak og effekt, klare dose-respons effekter og at alle sannsynlige forvekslingsfaktorer (confounders) heller vil bidra til å svekke enn å styrke den observerte sammenhengen mellom behandling og utfall. De forskjellige nivåene av kvalitet på dokumentasjonen som benyttes i GRADE er vist i tabell 3.

2. Estimering av relative og absolutte effekter for behandlingsalternativer blir gjennomført ved å applisere relative effektestimater (f. eks. relativ risiko med 95\% konfidensintervall) på risikoestimater for et gitt utfall (utgangsrisiko).

3. Utvikling av resultattabeller for dokumentasjonen på tvers av utfall: "Evidence Profiles" og "Summary of Findings"-tabeller (22-24).

Tabell 4 viser en "Summary of Findings"-tabell fra ACCP AT9. I tabellen ser vi at retningslinjegruppen hadde moderat til høy tillit til dokumentasjonen for at det antitrombotiske legemiddelet ticagrelor - sammenlignet med clopidogrel - gir 10 færre dødsfall og 16 færre hjerteinfarkt på bekostning av 6 flere større 
Tabell 4. Eksempel på resultattabell (Summary of Findings) utviklet i ACCP AT9, oversatt til norsk (8).

Ticagrelor + aspirin versus clopidogrel + aspirin hos pasienter med akutt koronarsyndrom

Bibliografi: Wallentin L, et al. Ticagrelor versus clopidogrel in patients with acute coronary syndromes. NEJM 2009; 361: 1045-57.

\begin{tabular}{|c|c|c|c|c|c|}
\hline \multirow[t]{2}{*}{ Utfall } & \multirow{2}{*}{$\begin{array}{l}\text { Deltakere } \\
\text { (studier) } \\
\text { Oppfølging }\end{array}$} & \multirow{2}{*}{$\begin{array}{l}\text { Kvalitet på do- } \\
\text { kumentasjonen } \\
\text { (GRADE) }\end{array}$} & \multirow{2}{*}{$\begin{array}{l}\text { Relativ effekt } \\
(95 \% \mathrm{CI})\end{array}$} & \multicolumn{2}{|c|}{ Forventede absolutte effekter i lopet av første året } \\
\hline & & & & $\begin{array}{c}\text { Risiko med } \\
\text { clopidogrel og } \\
\text { acetylsalicylsyre }\end{array}$ & $\begin{array}{c}\text { Risiko-forskjell med } \\
\text { ticagrelor og acetylsalicylsyre } \\
(95 \% \mathrm{CI}) \\
\end{array}$ \\
\hline Vaskulær mortalitet ${ }^{1}$ & $\begin{array}{l}18624 \\
(1 \mathrm{RCT}) \\
6-12 \text { måneder }\end{array}$ & $\begin{array}{l}\oplus \oplus \oplus \oplus \\
\mathbf{H \varnothing Y}\end{array}$ & $\begin{array}{l}\text { RR 0,79 } \\
(0,69 \text { til } 0,91)\end{array}$ & 50 per $1000^{2}$ & $\begin{array}{l}10 \text { færre døde per } \mathbf{1 0 0 0} \\
\text { (fra } 15 \text { færre til } 4 \text { færre) }\end{array}$ \\
\hline $\begin{array}{l}\text { Hjerteinfarkt (HI) } \\
\text { Ikke-fatale hendelser }\end{array}$ & $\begin{array}{l}18624 \\
(1 \mathrm{RCT}) \\
6-12 \text { måneder }\end{array}$ & $\begin{array}{l}\oplus \bigoplus \bigoplus \bigoplus \\
\mathbf{H Ø Y}\end{array}$ & $\begin{array}{l}\text { RR 0,84 } \\
(0,67 \text { til } 0,89)\end{array}$ & 70 per $1000^{2}$ & $\begin{array}{c}11 \text { færre hjerteinfarkt per } \mathbf{1 0 0 0} \\
\text { (fra } 17 \text { færre til } 3 \text { færre) }\end{array}$ \\
\hline $\begin{array}{l}\text { Hjerneslag } \\
\text { Inkluderer non-fatale } \\
\text { iskjemiske og } \\
\text { hemoragiske slag }\end{array}$ & $\begin{array}{l}18624 \\
(1 \mathrm{RCT}) \\
6-12 \text { måneder }\end{array}$ & $\begin{array}{l}\oplus \oplus \oplus O \\
\text { MODERAT } \\
\text { pga upresise } \\
\text { effektestimater }^{3}\end{array}$ & $\begin{array}{l}\text { RR 1,17 } \\
(0,91 \text { til } 1,52)\end{array}$ & 13 per $1000^{2}$ & $\begin{array}{l}\text { Ingen signifikant forskjell } \\
2 \text { flere hjerneslag per } 1000 \\
\text { (fra } 1 \text { færre til } 7 \text { flere) }\end{array}$ \\
\hline $\begin{array}{l}\text { Større ekstrakraniell } \\
\text { blødning }\end{array}$ & $\begin{array}{l}18624 \\
(1 \mathrm{RCT}) \\
6-12 \text { måneder }\end{array}$ & $\begin{array}{l}\oplus \oplus \oplus O \\
\text { MODERAT } \\
\text { pga upresise } \\
\text { effektestimater }\end{array}$ & $\begin{array}{l}\text { RR 1,25 } \\
(1,01 \text { til } 1,53)\end{array}$ & 22 per $1000^{2}$ & $\begin{array}{c}6 \text { flere per } 1000 \\
\text { (fra } 0 \text { flere til } 11 \text { flere) }\end{array}$ \\
\hline
\end{tabular}

${ }^{1}$ Av dødsfall sammenlagt i PLATO: 20/ 399 (5\%) var fatale blødninger med ticagrelor og 23/506 (4,5\%) var fatale blødninger m/ clopidogrel.

${ }^{2} 1$ års kontrollgruppe risikoestimater er hentet fra PLATO, hendelser rapportert ved 12 måneder.

${ }^{3}$ Redusert tillit til effektestimatene pga vide konfidensintervaller som inkluderer mulig skade med ticagrelor mht hjerneslag og blødninger.

${ }^{4}$ Av totale antall hjerneslag i PLATO: 23/ 125 (18\%) var hemoragiske med ticagrelor og 13/106 (12\%) var hemoragiske med clopidogrel.

blødninger (per 1000 pasienter behandlet i 12 måneder etter akutt koronarsyndrom) (8). Dokumentasjonen er her basert på én godt utført randomisert kontrollert studie. Kvaliteten på dokumentasjonen ble justert ned for hjerneslag og større blødninger på grunn av upresise absolutte effektestimater. Den øvre grensen av konfidensintervallet tilsier at ticagrelor i verste fall kan medføre 7 flere hjerneslag og 11 flere større blødninger hvilket betyr at det er en betydelig risiko for skade ved behandlingen. Retningslinjepanelet konkluderte med en samlet moderat tiltro til effektestimatene på tvers av utfallene, til tross for isolert sett høy tillit til effektestimatet for det mest kritiske utfallet, død. I denne overordnede vurderingen vektla panelet at det kun er utført én randomisert kontrollert studie for problemstillingen, som var industrifinansiert, og at man har begrenset dokumentasjon for bruk av det nye legemiddelet ticagrelor i klinisk praksis.

\section{Hvordan gå fra dokumentasjon til sterke eller svake anbefalinger?}

Med bruk av GRADE legges det opp til en systematisk og transparent vurdering av faktorer som er relevante for utvikling av anbefalinger. Dermed skal det være mulig å forstå - og etterprøve - retningslinjegruppens vurderinger (12). Det er i første rekke følgende fire faktorer som legges til grunn for den endelige anbefalingen:
1. Balansen mellom fordeler (ønskede konsekvenser) og ulemper (uønskede konsekvenser) for de aktuelle behandlingsalternativene.

2. Kvaliteten på dokumentasjonen (grad av tillit til effektestimatene, som beskrevet over).

3. Pasientverdier og preferanser. Hva ville pasientene ønsket, dersom de var godt informert om fordeler og ulemper ved behandlingsalternativene?

4. Kostnadsvurderinger. Utgjør behandlingen en fornuftig bruk av helseressurser?

Styrken på anbefalingen blir i henhold til GRADE bestemt ut fra følgende prinsipper:

Sterk anbefaling: Det er klart at fordelene veier opp for ulempene.

Svak anbefaling: Det er uklart om fordelene veier opp for ulempene.

Implikasjoner av en sterk anbefaling vil for de ulike aktørene være:

- Alle, eller nær sagt alle, pasienter vil ønske det anbefalte tiltaket - kun få vil ikke ønske det.

- Helsepersonell bør derfor tilby alle, eller nær sagt alle, pasienter det anbefalte tiltaket.

- Helsebyråkrater vil mene at anbefalingen bør gjelde som rutine, og at innholdet $i$ anbefalingen er egnet som kvalitetsindikator.

Implikasjoner av en betinget/svak anbefaling vil være: 
- De fleste pasienter vil ønske det anbefalte tiltaket, men mange vil ikke ønske det.

- Helsepersonell bør anerkjenne at ulike pasienter vil treffe ulike valg, og bør være forberedte på å hjelpe pasienter til å ta en avgjørelse som er i samsvar med pasientens egne verdier og preferanser. Verktøy for beslutningsstøtte kan være nyttig.

- Beslutningstakere vil kunne mene det er behov for debatt og involvering av interessegrupper, og at eventuell bruk av innholdet $i$ anbefalingen som kvalitetsindikator bør ta høyde for variasjon.

\section{Hva ville godt informerte pasienter valgt?}

Pasienters verdier og preferanser spiller en viktig rolle når balansen mellom fordeler og ulemper av ulike behandlingsalternativer skal vurderes. Anbefalinger som gjelder antitrombotisk behandling må sette redusert risiko for trombotiske hendelser opp mot økt risiko for blødninger og de praktiske ulemper som behandlingen innebærer. I forbindelse med utviklingen av ACCP AT9 ble det utarbeidet en systematisk oversikt over studier som har kartlagt pasienters preferanser (25). Ett sentralt funn var at det var stor variabilitet i pasienters preferanser og verdier relatert til antitrombotisk behandling. Dette er godt illustrert i en studie som stilte spørsmålet "Hvor mange blødninger er pasienter med atrieflimmer villige til å akseptere for å unngå ett hjerneslag?" - som er de viktigste ulempene og fordelene ved antikoagulasjonsbehandling med warfarin for denne pasientgruppen (26). Den systematiske oversikten ble så benyttet som grunnlag for utvikling av anbefalingene i ACCP AT9 (9).

\section{Hvordan inkludere kostnadsvurderinger $i$ retningslinjene?}

Anerkjente prinsipper for å inkorporere kost-/nyttevurderinger $\mathrm{i}$ utvikling av anbefalinger ble lagt til grunn i ACCP AT9 $(9,27)$. Økonomisk evaluering med innhenting av kost-/nytteanalyser ble kun utført der det var sannsynlig at slike analyser kunne endre retning eller styrke på anbefalingen. For å sikre at ressursbruk inngikk i vurderingene, var helseøkonomer med klinisk kompetanse med på å utvikle anbefalingene.

\section{Hva ble anbefalingen for ticagrelor i ACCP AT9?}

Retningslinjegruppen kom fram til følgende anbefaling (oversatt til norsk) gjennom en integrert vurdering av balansen mellom fordeler og ulemper, kvalitet på dokumentasjonen, verdier/ preferanser og ressursbruk:

Valg av type platehemmere de første 12 måneder etter gjennomgått akutt koronarsyndrom:

Vi foreslår ticagrelor $90 \mathrm{mg}$ daglig framfor clopidogrel $75 \mathrm{mg}$ dag, i tillegg til lavdosert acetylsalicylsyre 75 mg-100 mg de første 12 måneder (svak anbefaling/ moderat kvalitet på dokumentasjonen).

I denne anbefalingen er det forsøkt å gi en entydig anbefaling for klinisk praksis. Det går klart fram hvilke pasienter anbefalingen gjelder for, og i hvilke situasjoner anbefalingen skal anvendes.
Svake anbefalinger er velegnet for gode klinikere

AT9 er et omfattende retningslinjedokument, med rundt 600 anbefalinger. Om lag 400 av disse endte opp som svake anbefalinger. Overvekten av svake anbefalinger reflekterer at det innen antitrombotisk behandling ofte er en fin balanse mellom fordeler og ulemper. Når det gis svake anbefalinger er det viktig at klinikerne som skal bruke retningslinjen gis tilgang til kunnskapsgrunnlaget slik at anbefalingene kan skreddersys den enkelte pasient, gjerne gjennom en samtale med pasientene om fordeler og ulemper ved de aktuelle behandlingsmåtene. Ved svake anbefalinger er det spesielt viktig at pasientens preferanser og verdier tas inn $\mathrm{i}$ vurderingen når det skal velges mellom forskjellige behandlingsalternativer (28). Anbefalingen for ticagrelor illustrerer hvordan omfattende vitenskapelig dokumentasjon basert på en godt utført randomisert kontrollert studie kan resultere i en svak anbefaling. I dette tilfellet vurderte retningslinjegruppen at fordelene ikke klart veide opp for ulempene. Dermed ble det konkludert at de fleste pasienter, men slett ikke alle, antakelig vil velge ticagrelor framfor clopidogrel.

\section{Håndtering av interessekonflikter}

Det er bred internasjonal enighet om at registrering og rapportering av interessekonflikter er nødvendig for å sikre god kvalitet på faglige retningslinjer (5). Det er også økende forståelse for at intellektuelle interessekonflikter er vel så viktige som økonomiske interessekonflikter (2). I arbeidet med å utvikle ACCP AT9 ble begge typer interessekonflikter systematisk registrert. Det ble skilt mellom "primære" og "sekundære" interessekonflikter basert på graden av antatt påvirkning på retningslinjearbeidet $(9,29)$. For eksempel ble deltakere som selv hadde utført sentrale studier regnet som å ha en primær intellektuell interessekonflikt, og deltakere med primære interessekonflikter fikk ikke delta i den endelige utformingen av anbefalinger. Alle registrerte interessekonflikter ble publisert sammen med retningslinjen.

\section{NY GENERASJON TROVERDIGE RETNINGS- LINJER I BRUKERVENNLIGE FORMATER}

Erfaringene blant annet fra utviklingen av ACCP AT9, illustrerer mange av utfordringene knyttet til utvikling av troverdige retningslinjer: Det stilles store krav både til tid, metodekompetanse og klinisk ekspertise. Oppdatering av ACCP AT9 retningslinjene omfattet 128 internasjonale eksperter som arbeidet i to år. Retningslinjen ble publisert i 2012, men allerede nå har nye studier innen antitrombotisk behandling medført at en del anbefalinger er utdaterte. Manglende oppdatering av retningslinjer er et velkjent problem (30). I og med at det svært ressurskrevende å utvikle slike retningslinjer, er det viktig å legge til rette for nasjonal og lokal tilpasning av anbefalingene, for å unngå unødig dobbeltarbeid. 
Svak
Det er usikkert om fordelene veier opp for ulempene. De fleste pasienter vil fortsatt ønske den anbefalte behandlingen, men det er større mulighet for individuell variasjon

Vi foreslår acetylsalisylsyre $75 \mathrm{mg} \times 1$ pluss ticagrelor $90 \mathrm{mg} \times 2$ framfor acetylsalisylsyre pluss klopidogrel.

Merknad: Ved høy blødningsrisiko (f. eks. antikoagulerte pasienter) anbefales kombinasjonen klopidogrel og acetylsalisylsyre.

Dokumentasjon Nøkkelinfo Rasjonale Praktisk info Alternativer Adaptasjon Ref Kommentarer (0)

Fordeler og ulemper

Hos 1000 pasienter behandlet i 1 år:

Behandling med klopidogrel og acetylsalisylsyre vil føre til 16 færre hjerteinfarkter sammenliknet med acetylsalisylsyre alene, men gi 11 flere alvorlige ekstrakranielle blødninger.

Behandling med kombinasjonen ticagrelor og acetylsalisylsyre vil gi 10 færre dødsfall og 11 færre hjerteinfarkter sammenliknet med kombinasjonen klopidogrel og acetylsalisylsyre, men gi 6 flere alvorlige ekstrakranielle blødninger.

Kvalitet på dokumentasjonen

Văr tiltro til effektestimatene for kombinasjonen klopidogrel og acetylsalisylsyre vs acetylsalisylsyre alene er høy for hjerteinfarkt, men moderat for vaskulær død, slag og blødning grunnet upresise estimater.

Vår tiltro til effektestimatene for kombinasjonen ticagrelor og acetylsalisylsyre vs klopidogrel og acetylsalisylsyre er moderat pga upresise effektestimater for hjerneslag og alvorlig blødning.

Dobbel platehemmende behandling med ticagrelor og acetylsalisylsyre er ikke studert hos pasienter som bruker warfarin.

Verdier og preferanser
Da gevinsten ved dobbel platehemming er stor i denne pasientgruppen, antar vi at de fleste vil foretrekke dobbel framfor enkel platehemming til tross for noe økt blødningsrisiko.

Da gevinsten ved ticagrelor framfor klopidogrel er betydelig hos pasienter med normal eller lav blødningsrisiko, antar vi at de fleste pasienter vil foretrekke kombinasjonen ticagrelor og acetylsalisylsyre framfor kombinasjonen klopidogrel og acetylsalisylsyre. Pasienter som foretrekker dosering en gang daglig kan komme til å velge klopidogrel.

Ressurshensyn

Kombinasjonsbehandling med acetylsalisylsyre og klopidogrel i inntil 1 år er funnet å være kostnadseffektivt. Behandling med kombinasjonen ticagrelor og acetylsalisylsyre er vesentlig dyrere enn kombinasjonen klopidogrel og acetylsalisylsyre. Det er innvilget forhåndsgodkjent refusjon for både klopidogrel og ticagrelor (ICD-10 kode I21-22).

Figur 1. Eksempel på "topplokk" med nøkkelinformasjon, ett tastetrykk unna anbefalingen, for pasienter med akutt koronarsyndrom.

For å oppnå mer effektiv utvikling, disseminering og oppdatering av troverdige faglige retningslinjer er det etablert et internasjonalt forskningsprogram: "Making GRADE the Irresistible Choice" (MAGIC) (10). I MAGIC-prosjektet tilpasses og oversettes ACCP AT9 til en norsk retningslinje for antitrombotisk behandling og tromboseprofylakse. For å legge til rette for effektiv utvikling av retningslinjer er det utviklet et nettbasert forfatterverktøy og en publiseringsplattform (MAGICapp) som tillater parallell utvikling og publisering av retningslinjer på nett, brett og smarttelefoner, samt at anbefalingene kan integreres i elektroniske pasientjournaler.

Like viktig som at kliniske retningslinjer inneholder gode, troverdige anbefalinger, er det å sikre at de blir benyttet i praksis, i møtet med den enkelte pasient. Det er velkjent at faglige retningslinjer $\mathrm{i}$ varierende - og kanskje overraskende liten - grad har en innvirkning på klinisk praksis. Blant en rekke faktorer som kan bidra til bedre implementering av kliniske retningslinjer er effektiv disseminering ut til frontlinjen i klinikken (6). De fleste troverdige retningslinjer, også ACCP AT9, har klare begrensninger i så måte fordi de i første rekke publiseres som dokumenter, på en måte som gjør dem vanskelig å finne, forstå og bruke.

I MAGIC utvikles det derfor også verktøy som leger og pasienter kan bruke i kliniske konsultasjoner for å dele kunnskap om fordeler og ulemper av behandling (28,31). Formatet som de norske kliniske retningslinjene for antitrombotisk behandling blir presentert $i$, kan fungere som verktøy for kunnskapsstøtte på ulike plattformer. Presentasjonsformatene som benyttes for de norske retningslinjene for antitrombotisk behandling er utviklet gjennom omfattende forskning og brukertesting med leger i sju land gjennom samarbeid mellom MAGIC-prosjektet og det EU-finansierte prosjektet DECIDE (6). Formatene skal gi klinikeren tilgang til anbefalinger og kunnskapsgrunnlag i løpet av to minutter. Figur 1 viser ett eksempel på et såkalt "topplokk" som definerer det minimum av informasjon klinikeren trenger for å kunne applisere anbefalinger $\mathrm{i}$ praksis. I tillegg vil det til hver enkelt anbefaling være knyttet relevante resultattabeller (Summary of Findings-tabeller), praktisk informasjon, samt verktøy for å beregne hvor utsatt den enkelt pasient er for å rammes av aktuelle utfall (risikostratifisering).

\section{VEIEN VIDERE}

Det er gjort store framskritt innen standarder, metoder og verktøy for utvikling, disseminering og oppdatering av troverdige kliniske retningslinjer. Dette gir langt bedre muligheter enn tidligere for å sikre pasienter diagnostikk, pleie og behandling tråd med beste tilgjengelige forskningsbaserte kunnskap, klinisk ekspertise og pasientpreferanser/verdier.

Ett sentralt spørsmål er hvordan en best kan lykkes $\mathrm{i}$ arbeidet med både å utvikle og tilgjengeliggjøre retningslinjer for klinisk praksis. Viktige steg på veien er erkjennelsen av at slike retningslinjer utgjør et funda- 
ment for arbeid med kvalitet og pasientsikkerhet, samt å operasjonalisere nye standarder for utvikling av troverdige retningslinjer, slik de blant annet er beskrevet $i$ Helsedirektoratets nye veileder for utvikling av kunn- skapsbaserte retningslinjer. Det kreves ressurser både i form av tid og kompetanseheving, både i metode- og $\mathrm{i}$ fagmiljøene som er engasjert i utvikling av kliniske retningslinjer.

\section{REFERANSER}

1. Laine C, Taichman DB, Mulrow C. Trustworthy clinical guidelines. Ann Intern Med 2011; 154 (11): 774-5.

2. Shaneyfelt T. In guidelines we cannot trust: Comment on "Failure of clinical practice guidelines to meet institute of medicine standards". Arch Intern Med 2012; 172 (21): 1633-4.

3. Alonso-Coello P, Irfan A, Sola I, Gich I, Delgado-Noguera M, Rigau D, et al. The quality of clinical practice guidelines over the last two decades: a systematic review of guideline appraisal studies. Qual Saf Health Care 2010; 19 (6): e58.

4. Guyatt GH, Oxman AD, Schunemann HJ, Tugwell P, Knottnerus A. GRADE guidelines: a new series of articles in the Journal of Clinical Epidemiology. J Clin Epidemiol 2011; 64 (4): 380-2.

5. Qaseem A, Forland F, Macbeth F, Ollenschlager G, Phillips S, van der Wees P. Guidelines International Network: toward international standards for clinical practice guidelines. Ann Intern Med 2012; 156 (7): 525-31.

6. Treweek S, Oxman AD, Alderson P, Bossuyt PM, Brandt L, Brozek J, et al. Developing and evaluating communication strategies to support informed decisions and practice based on evidence (DECIDE): protocol and preliminary results. Implement Sci 2013; 8: 6 .

7. Guyatt GH, Akl EA, Crowther M, Gutterman DD, Schuunemann HJ. Executive summary: Antithrombotic Therapy and Prevention of Thrombosis, 9th ed: American College of Chest Physicians Evidence-Based Clinical Practice Guidelines. Chest 2012; 141 (2 Suppl): 7S-47S.

8. Vandvik PO, Lincoff AM, Gore JM, Gutterman DD, Sonnenberg FA, Alonso-Coello P, et al. Primary and secondary prevention of cardiovascular disease: Antithrombotic Therapy and Prevention of Thrombosis, 9th ed: American College of Chest Physicians Evidence-Based Clinical Practice Guidelines. Chest 2012; 141 (2 Suppl): e637S-68S.

9. Guyatt GH, Norris SL, Schulman S, Hirsh J, Eckman MH, Akl EA, et al. Methodology for the development of antithrombotic therapy and prevention of thrombosis guidelines: Antithrombotic Therapy and Prevention of Thrombosis, 9th ed: American College of Chest Physicians Evidence-Based Clinical Practice Guidelines. Chest 2012; 141 (2 Suppl): 53S-70S.

10. Vandvik PO, Brandt L, Alonso-Coello P, Treweek S, Akl EA, Kristiansen A, et al. Creating clinical practice guidelines we can trust, use and share: A new era is imminent. Chest 2013; 144 (2): 381-9.

11. Guyatt GH, Oxman AD, Vist GE, Kunz R, Falck-Ytter Y, Alonso-Coello P, et al. GRADE: an emerging consensus on rating quality of evidence and strength of recommendations. BMJ 2008; 336 (7650): 924-6.

12. Guyatt GH, Oxman AD, Kunz R, Falck-Ytter Y, Vist GE, Liberati A, et al. Going from evidence to recommendations. BMJ 2008; 336 (7652): 1049-51.

13. GRADE working group. Organizations that have endorsed or that are using GRADE. http://www.gradeworkinggroup.org/society/index.htm (08.08.13).

14. Veileder for utvikling av kunnskapsbaserte retningslinjer. Oslo: Helsedirektoratet, 2012.

15. Committee on Standards for Developing Trustworthy Clinical Practice Guidelines, Institute of Medicine of the National Academies. Clinical Practice Guidelines We Can Trust. Washington, D.C.: National Academies Press, 2011.

16. Kirkehei I, Ormstad SS. Litteratursøk. Norsk Epidemiologi 2013; 23 (2): 141-145.

17. Jamtvedt G. Systematiske oversikter om effekt av tiltak. Norsk Epidemiologi 2013; 23 (2): 119-124.

18. Guyatt GH, Oxman AD, Kunz R, Atkins D, Brozek J, Vist G, et al. GRADE guidelines: 2. Framing the question and deciding on important outcomes. J Clin Epidemiol 2011; 64 (4): 395-400.

19. Spencer FA, Iorio A, You J, Murad MH, Schunemann HJ, Vandvik PO, et al. Uncertainties in baseline risk estimates and confidence in treatment effects. BMJ 2012; 345: e7401.

20. Guyatt GH, Oxman AD, Kunz R, Vist GE, Falck-Ytter Y, Schunemann HJ. What is "quality of evidence" and why is it important to clinicians? BMJ 2008; 336 (7651): 995-8.

21. Guyatt G, Oxman AD, Sultan S, Brozek J, Glasziou P, Alonso-Coello P, et al. GRADE guidelines: 11. Making an overall rating of confidence in effect estimates for a single outcome and for all outcomes. $J$ Clin Epidemiol 2013; 66 (2): 151-7.

22. Guyatt G, Oxman AD, Akl EA, Kunz R, Vist G, Brozek J, et al. GRADE guidelines: 1. Introduction-GRADE evidence profiles and summary of findings tables. J Clin Epidemiol 2011; 64 (4): 383-94. 
23. Vandvik PO, Santesso N, Akl EA, You J, Mulla S, Spencer FA, et al. Formatting modifications in GRADE evidence profiles improved guideline panelists comprehension and accessibility to information. A randomized trial. J Clin Epidemiol 2012; 65 (7): 748-55.

24. Glenton C, Rosenbaum S. Cochrane i Norge - Hvordan formidler vi resultatene fra Cochrane-oversikter? Norsk Epidemiologi 2013; 23 (2): 215-219.

25. MacLean S, Mulla S, Akl EA, Jankowski M, Vandvik PO, Ebrahim S, et al. Patient values and preferences in decision making for antithrombotic therapy: a systematic review: Antithrombotic Therapy and Prevention of Thrombosis, 9th ed: American College of Chest Physicians Evidence-Based Clinical Practice Guidelines. Chest 2012; 141 (2 Suppl): e1S-23S.

26. Devereaux PJ, Anderson DR, Gardner MJ, Putnam W, Flowerdew GJ, Brownell BF, et al. Differences between perspectives of physicians and patients on anticoagulation in patients with atrial fibrillation: observational study. BMJ 2001; 323 (7323): 1218-22.

27. Guyatt GH, Oxman AD, Kunz R, Jaeschke R, Helfand M, Liberati A, et al. Incorporating considerations of resources use into grading recommendations. BMJ 2008; 336 (7654): 1170-3.

28. Stiggelbout AM, Van der Weijden T, De Wit MP, Frosch D, Legare F, Montori VM, et al. Shared decision making: really putting patients at the centre of healthcare. $B M J 2012 ; 344$ : e256.

29. Guyatt G, Akl EA, Hirsh J, Kearon C, Crowther M, Gutterman D, et al. The vexing problem of guidelines and conflict of interest: a potential solution. Ann Intern Med 2010; 152 (11): 738-41.

30. Alonso-Coello P, Martinez Garcia L, Carrasco JM, Sola I, Qureshi S, Burgers JS. The updating of clinical practice guidelines: insights from an international survey. Implement Sci 2011; 6: 107.

31. van der Weijden T, Boivin A, Burgers J, Schunemann HJ, Elwyn G. Clinical practice guidelines and patient decision aids. An inevitable relationship. J Clin Epidemiol 2012; 65 (6): 584-9. 